\title{
JOINT SHAFT TEST STAND
}

\section{JIŘí PAKOSTA, GABRIELA ACHTENOVÁ}

CTU in Prague, Faculty of Mechanical Engineering, Department of Automotive, Combustion Engine and Railway Engineering jiri.pakosta@fs.cvut.cz, gabriela.achtenova@fs.cvut.cz

\section{ABSTRACT}

The article focuses on description of design of the test stand for shafts with universal joints and constant velocity joints. The shafts can be loaded by torque at specified speed of rotation, while retaining the possibility of setting a variable angle between input and output. All shafts are instrumented with contactless signal transmission. In addition, ventilator simulates the cooling derived from the driving speed.

\section{KEYWORDS: HOOKE'S JOINT, CV-JOINT, TEST STAND}

\section{SHRNUTÍ}

Článek popisuje zkušební stav pro měření kloubových hřídelů. Hřídele mohou být zatěžovány točivým momentem při různých otáčkách a měnícím se úhlu zlomu. Měřené hřídele jsou vybaveny snímaním teploty kloubů s telemetrickou soupravou přenosu signálu. Klouby jsou chlazeny náporovým ventilátorem, který simuluje ochlazování kloubů při jízdě vozidla.

KLíČOVÁ SLOVA: KŘíŽOVÉ KLOUBY, HOMOKINETICKÉ KLOUBY, ZKUŠEBNII ZAŘíZENÍ

\section{INTRODUCTION}

Joint shafts of drive axles are increasingly used types of wheel drives in passenger automobile drive trains. In steerable drive axles, constant-velocity joints are the only way how driving power can be transmitted to the driving wheels in a conventional drive train with a combustion engine. Thorough description of used types, their design and calculation can be found in [1]. Brief overview of joint shaft is covered in [2].

Great progress can be seen recently in the area of creation of virtual prototypes where the product designed is replaced with a computer simulation model. The virtual prototype tries to verify the in-service behavior of the real product without having to manufacture it. The virtual prototype is created using mathematic modeling methods which cover stress-strain and dynamic analyses, heat transmission, flow dynamics, acoustics, and a number of other physical processes. Each mathematic model, however, is based on simplifying hypotheses which only approximate, to a greater or lesser extent, the actual solution, and much of the input data for the mathematic model is obtained through experiments using simplified realistic models. The mathematic models thus reduce the required number of test prototypes manufactured, although they do not eliminate the need for them entirely. Therefore production of realistic prototypes and testing equipment for testing new components is still important today and is covered in this article. The article describes the newly created test stand for testing of joint shafts in the laboratories of the Department of Automotive, Combustion Engine and Railway Engineering.

\section{TEST STAND CONCEPT}

In order to use the test stand to simulate the actual behavior of drive shafts in a vehicle as accurately as possible, the stand must imitate the operating conditions as much as possible. In addition, it must include a number of sensors for automation, diagnostics and evaluation of the test. The stand should serve for tests of joint shafts with universal joints as well as shafts with constant velocity joints. As the majority of passenger vehicles are designed with transverse power unit and front axle drive where the use of constant velocity joints is inevitable, the stand was set up and primarily tested for the tests of these shafts.

The operating conditions are defined by the torque at specified speed (rpm) and the set bend angle. The joint shaft is loaded 
with the driving or braking torque between the engine and the transmission gear and the wheel of the vehicle. The rotation speed of the joint shaft is directly proportional to the driving speed of the vehicle. The bend angle ranges between its minimum and maximum design value.

The test stand can be designed as an open or closed test stand. A closed test stand has the advantage consisting of lower energy demand of long-term tests, but its closed space design significantly complicates the tests of various lengths of jointed shafts and a broader range of the bend angles. Therefore an open test stand has been selected as a test stand concept.

\section{OPEN TEST STAND FOR JOINT SHAFT TESTING}

The open test stand consists of the input drive dynamometer which is controlled to constant torque, and the output dynamometer controlled to constant rotation speed. The scheme of the stand is depicted on Figure 1. The input dynamometer is placed on the profile rail linear guide in longitudinal direction (in the direction of the dynamometer axis). This dynamometer is a two shafts asynchronous dynamometer. The eddie current output dynamometer is placed on linear guide system in transverse direction (perpendicular to the dynamometer axis). This linear guide system consists of a pair of rails and four ball-bearing carriages. The rails are attached with fasteners to the base plate of the testing site; the ball-bearing carriages are attached with screws to the dynamometer frame. Positioning of the dynamometers is facilitated by the use of screw jacks controlling the mechanism of the lead screws. The main parameters of both dynamometers are listed in Table 1.

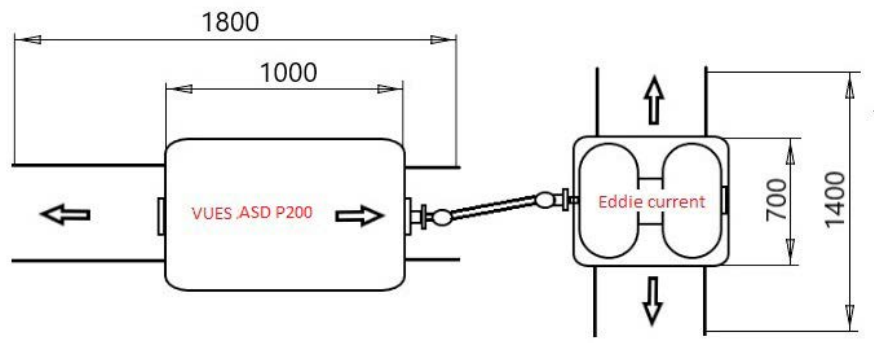

FIGURE 1: Scheme of the set-up for joint shaft experimental testing OBRÁzEK 1: Schéma stavu pro zkoušky kloubových hřídelů

The position of the shaft in the vertical axis direction in the output dynamometer can be easily set by insertion of calibrated washers between the supporting frame and the dynamometer itself. This resulted in a universal station with the following characteristics:
- Easy and quick adjustment to different lengths of the joint shafts

- Easy change of the bend angles of the shafts.

If the axis of the movable dynamometer is set at the same height as the axis of the fixed dynamometer the subsequent setting of the bend angle only takes place in-plane, which makes the operation of the stand easier.

TABLE 1: Dynamometer parametres

TABULKA 1: Parametry dynamometrů

\begin{tabular}{lcc} 
Parameter & $\begin{array}{c}\text { Input dynamometer } \\
\text { Asynchronous }\end{array}$ & $\begin{array}{c}\text { Output dynamometer } \\
\text { Eddie current }\end{array}$ \\
\hline Type & ASD P200 & 2VD110/6 \\
\hline Specification & $7000 \mathrm{rpm}$ & $6000 \mathrm{rpm}$ \\
\hline Maximal rpm & 1100 & 800 \\
\hline Maximal torque [N.m] & 200 & 220 \\
\hline Maximal power [kW] & &
\end{tabular}

The stand is designed such that the axes of the dynamometers are parallel. It is therefore possible to test joint shafts with universal joints with " $\mathrm{Z}$ " and " $\mathrm{V}$ " bend configuration or, as the case may be, layout with the same space angles. If testing of the joint shaft layout with different joint angles is needed it is possible to deviate the axis of rotation of the output dynamometer to the space. Such configuration, however, would substantially complicate the set-up of the bend angles during the tests.

The bend axis is changed by the motion of the dynamometer in transversal axis. Dependence of the magnitude of the travel on the value of the bend angle is determined by the trigonometric function of transversal displacement of output dynamometer divided the length of the joint shaft. When testing constant bend angles of a joint shaft, it is possible to fix the dynamometer frame to the rail by pneumatically released friction brake. In tests with the changing bend angle, it is possible to drive the screw jack with programming capability using an electric motor.

In order to move the dynamometer during operation it was necessary to provide flexible lines of power supply, pressurized air, coolant and sensor conductors. For cooling of the joint shafts, the stand is additionally equipped with fans the cooling effect of which can be adjusted by the distance from the joint shaft or the value of the fan propeller rotation speed.

When driving in a vehicle, each joint is blown at by a different air flow. The joint on the gearbox side is typically "shielded" by the shape of the gearbox while the joint on the wheel side is cooled by air with substantially higher velocity. The velocities of the air blowing at each joint have been obtained from the vehicle manufacturers. In laboratory testing, where the joint 


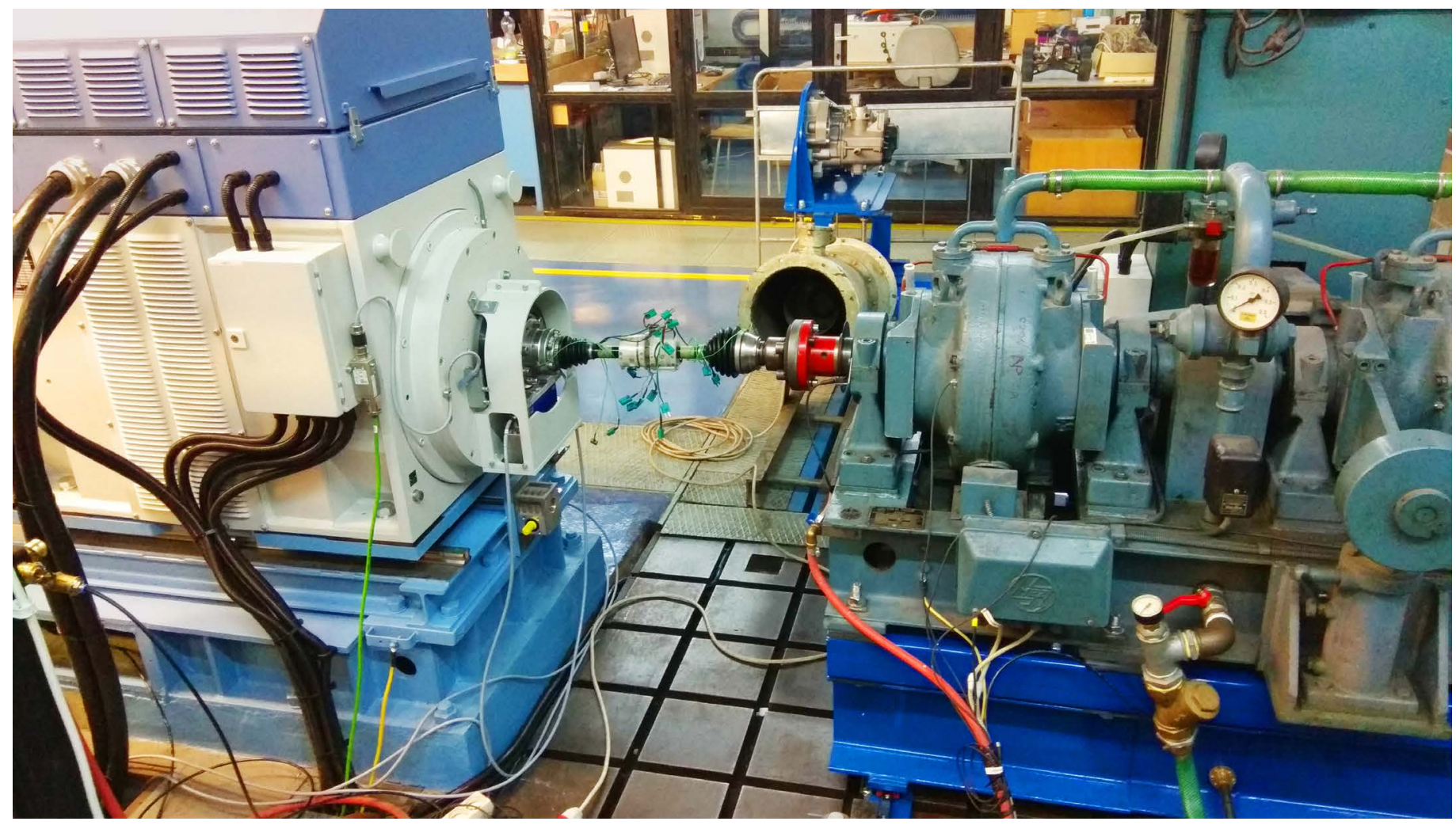

FIGURE 2: Open test stand for testing of joint shafts

OBRÁZEK 2: Otevřený zkušební stav pro zkoušky kloubových hřídelů

shaft is attached with screws directly to the dynamometer flanges, the following solutions are possible:

1. Using two fans of different parameters

2. Using a fixture for shielding a part of the airflow for the "gearbox joint",

3. Correct positioning of the fan such that greater amount of air would flow to the "wheel" joint.

We have opted for the third solution. The correct position of the cooling fan was determined by means of anemometric measurement of the velocity of the air blowing at the two joints. The final position was fixed in order to ensure repeatability of the measurement.

\section{MAGNITUDES MEASURED}

The value of the required load torque is set on the input dynamometer. The load torque corresponds to the one half of the driving torque of the vehicle needed to propel the vehicle on given constant speed on straight flat road. As example we assume the speed of the vehicle equals $175 \mathrm{~km} / \mathrm{h}$; the needed torque on one driving wheel equals $248 \mathrm{~N} . \mathrm{m}$. The torque measured on the output dynamometer is lower due to the efficiency of the joint shaft. When testing constant-velocity joint shafts, the input and output rotation speed is the same. The necessary speed of rotation $n$ is defined from the given vehicle speed $v$ with help of the dynamic radius of the tire $r$. The test parameters obtained for the mentioned assumption are listed in Table 2.

$n=\frac{v}{2 \pi r} \frac{1000}{60}$

The devices suitable as joint temperature sensors are, due to their minimal dimensions, thermocouple thermometers which are placed in drill holes in the joint body. Signal transmission from the rotating shaft is contactless. In addition, the measuring apparatus attached must be balanced in order to avoid additional load on the joint shaft measured.

TABLE 2: Example of test parameters

TABULKA 2: Ukázka zkušebních parametrů

\begin{tabular}{lc}
\hline Run-in torque for a bend angle of $7^{\circ}$ & $50 \mathrm{~N} . \mathrm{m}$ \\
\hline Time of run-in & $0,5 \mathrm{~h}$ \\
\hline Test load torque & $248 \mathrm{~N} \cdot \mathrm{m}$ \\
\hline Time of one measuremeng & $0,57 \mathrm{~h}$ \\
\hline Rpm of one half shaft & $1441 \mathrm{rpm}$ \\
\hline Tested bend angles & $7^{\circ}, 8^{\circ}, 9^{\circ} \mathrm{a} 10^{\circ}$
\end{tabular}




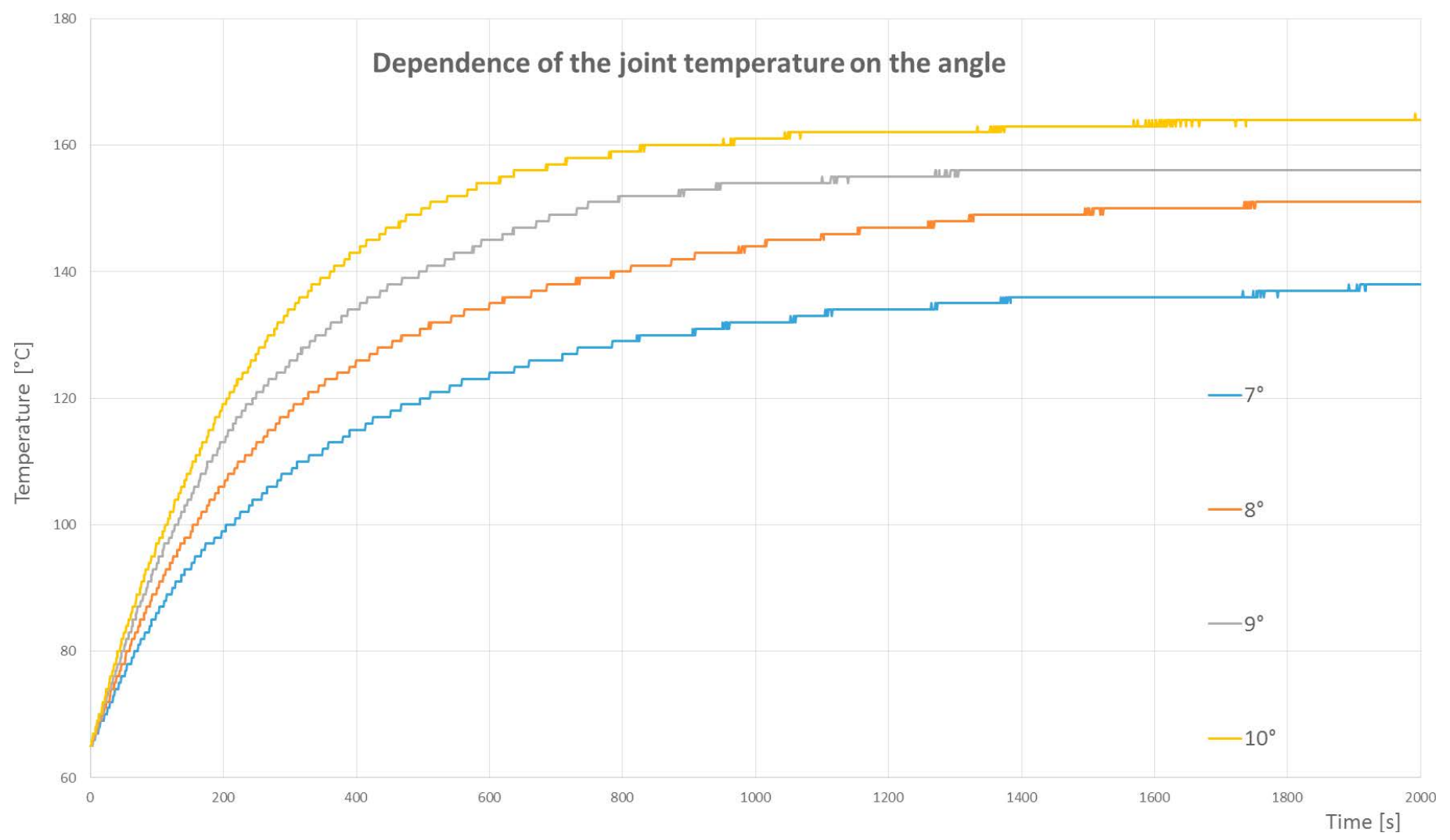

FIGURE 3: Dependence of the temperature of one selected CV joint of the automotive joint shaft on the bending angle.

OBRÁZEK 3: Závislost nárůstu teploty na úhlu zlomu u zkoušeného kloubového hřídele

Various measurements can be performed in the test stand, from functional tests up to lifespan measurements. In the present case, we measured dependence of the joint temperature on the changing bend angle. For one torque and speed level we measured the temperature dependence on the bend angle in most of the operating range of the joint shaft. The joints were cooled down to the original temperature between the individual measurements. The time of the measurement is determined as the necessary time needed to drive with a given speed $v$ the distance of $100 \mathrm{~km}$. For the speed of $175 \mathrm{~km} / \mathrm{h}$ the measurement time equals $34,2 \mathrm{~min}$. A sample of the temperatures measured during the test defined in Table 2 is depicted on Figure 3.

\section{CONCLUSION}

The correct design of the stand with mounting of dynamometers on linear sliding system was affirmed as fully functional by a test of different joint shafts focusing on the measurement of the increase of temperature of the joints depending on the changing bend angle. The test stand can be further equipped with the rotary encoder to obtain the value of non-uniform rotation of the joint shafts. As next is investigated the possibility of precise torque measurement to be capable to measure the efficiency of the joint shafts. This measurement with the nowadays equipment is not possible.

\section{ACKNOWLED GEMENT}

The authors would like to thank Škoda Auto, a.s. for provision of joint shafts, and for lending the unique system for measurement of temperatures of rotating shafts.

This research has been realized using the support of The Ministry of Education, Youth and Sports program NPU I (LO), project \# L01311 Development of Vehicle Centre of Sustainable Mobility.

Both supports are gratefully acknowledged.

\section{REFERENCES}

[1] Graf can Seherr_Thoss H. CH.: Gelenke und Gelenkwellen. Springer Verlag. 2002. ISBN 3-540-41759-1.

[2] Achtenová G., Klír V.: Převodná ústrojí motorových vozidel. Kloubové hřídele. CTN - nakladatelství ČVUT. 2012. ISBN 978-80-01-05129-0 